\title{
STRATEGI PERLINDUNGAN LAHAN PERTANIAN PANGAN BERKELANJUTAN DI KABUPATEN BOGOR
}

\author{
Strategy to Protect Agricultural Land for Sustainable Food Security in Bogor Regency \\ Judo Satria $^{1}$, A. Faroby Falatehan ${ }^{2}$, Irfan Syauqi Beik ${ }^{3}$ \\ 1 Staff Dinas Tanaman Pangan Hortikultura dan Perkebunan Pemerintah Kabupaten Bogor. Email: \\ j.satria14@gmail.com \\ ${ }^{2}$ Staff Pengajar Departemen Ekonomi Sumberdaya dan Lingkungan. Fakultas Ekonomi dan Manajemen IPB. \\ Email: robiefa@gmail.com \\ 3 Staff Pengajar Departemen Ilmu Ekonomi Syariah FEM Institut Pertanian Bogor (IPB). Fakultas Ekonomi \\ dan Manajemen IPB. Email: irfan_beik@ipb.ac.id
}

\begin{abstract}
Protection of sustainable food agriculture land is an efforts in order to control the high rate of conversion of agricultural land to non-agricultural land, as well as food security and sovereignty. In addition, agricultural land has a very strategic role and function for the people of Bogor District who are agrarian because there are a large number of residents of Bogor District who depend on the agricultural sector. This study aims to formulate the strategy of the Bogor District Government through a strategy to control the transformation of sustainable food agricultural land to meet the level of food sufficiency and protect from the rate of land conversion. To achieve these objectives, a review needs to be done to check the availability of agricultural land, with the formulation of Analytical Hierarchy Process for policy development decision
\end{abstract}

Keywords: agricultural land conversion, agricultural land protection strategy.

\begin{abstract}
ABSTRAK
Perlindungan lahan pertanian pangan berkelanjutan merupakan salah satu upaya dalam rangka pengendalian terhadap tingginya laju alih fungsi lahan pertanian ke lahan non-pertanian. Serta terkait pula dengan ketahanan dan kedaulatan pangan. Disamping itu, lahan pertanian memiliki peran dan fungsi yang sangat strategis bagi masyarakat Kabupaten Bogor yang bercorak agraris karena terdapat sejumlah besar penduduk Kabupaten Bogor yang menggantungkan hidup pada sektor pertanian. Penelitian ini bertujuan untuk merumuskan strategi Pemerintah Kabupaten Bogor melalui strategi pengendalian alihfungsi lahan pertanian pangan berkelanjutan guna memenuhi tingkat kecukupan pangan dan melindungi dari laju konversi lahan. Untuk mencapai tujuan tersebut maka dilakukan tinjauan terhadap ketersediaan lahan peruntukan pertanian, dengan perumusan Proses Hirarki Analitik untuk keputusan pengembangan kebijakan
\end{abstract}

Kata Kunci : alihfungsi lahan pertanian, strategi perlindungan lahan pertanian

\section{PENDAHULUAN}

Alih fungsi lahan sesungguhnya bukan fenomena baru dalam kehidupan manusia. Fenomena ini sudah berlangsung lama, bahkan mungkin seusia dengan peradaban manusia Sejalan dengan pertumbuhan populasi, penguasaan dan penggunaan lahan bermasalah. Hal ini memunculkan 
lahan.

Permasalahan utama Kabupaten Bogor dalam mewujudkan kemandirian, ketahanan dan kedaulatan pangan terkait dengan lahan pertanian adalah pertumbuhan permintaan pangan lebih cepat dari penyediaan pangan, akibat pertumbuhan penduduk, pertumbuhan ekonomi, daya beli dan pola konsumsi masyarakat, dan kecepatan alih fungsi lahan serta upaya pembukaan lahan baru yang masih rendah. Permintaan tanah untuk keperluan pembangunan berbagai sektor kegiatan antara lain; industri, perdagangan, perkebunan, infrastruktur dan fasilitas penunjang kegiatan lainnya terus mengalami peningkatan seiring dengan lajunya tingkat pembangunan dan pertambahan penduduk merupakan tantangan dalam upaya mempertahankan penyediaan lahan untuk pemenuhan kebutuhan pangan daerah.

Kabupaten Bogor sebagai daerah penyangga Ibu Kota Negara berkembang dengan cepat baik dari sisi pertumbuhan penduduk, ekonomi maupun infrastruktur. Berdasarkan data BPS terakhir, laju pertumbuhan penduduk Kabupaten Bogor cukup tinggi yaitu sekitar 2,41\% terlihat pada Tabel 1 .

Tabel 1. Jumlah Penduduk berdasarkan sensus Penduduk Tahun 2010 dan estimasi Penduduk Tahun 2014 s/d 2017

\begin{tabular}{cccccc}
\hline \hline \multirow{3}{*}{ Kabupaten } & \multicolumn{5}{c}{ Jumlah Penduduk (ribu) Population (thousand) } \\
\cline { 2 - 6 } & $\mathbf{2 0 1 0}$ & $\mathbf{2 0 1 4}$ & $\mathbf{2 0 1 5}$ & $\mathbf{2 0 1 6}$ & $\mathbf{2 0 1 7}$ \\
\hline$(1)$ & $(2)$ & $(3)$ & $(4)$ & $(5)$ & $(6)$ \\
\hline \multirow{2}{*}{ Bogor } & $\mathbf{4 . 7 7 1 . 9 3 2}$ & $\mathbf{5 . 3 3 1 . 1 4 9}$ & $\mathbf{5 , 4 5 9 , 6 6 8}$ & $\mathbf{5 , 5 8 7 , 3 9 0}$ & $\mathbf{5 , 7 1 5 , 0 0 9}$ \\
\hline \hline
\end{tabular}

Sumber: BPS Kabupaten Bogor

Kepadatan penduduk di perkotaan memberikan pengaruh terhadap peningkatan penduduk di wilayah yang dekat dengan pusat pertumbuhan kota. Konversi lahan pertanian di wilayah pinggiran kota menjadi alternatif yang dilakukan untuk mengatasi persoalan pertambahan penduduk. Oleh karena itu, konversi lahan semakin sulit untuk dikendalikan. Terlihat pada Gambar 1.

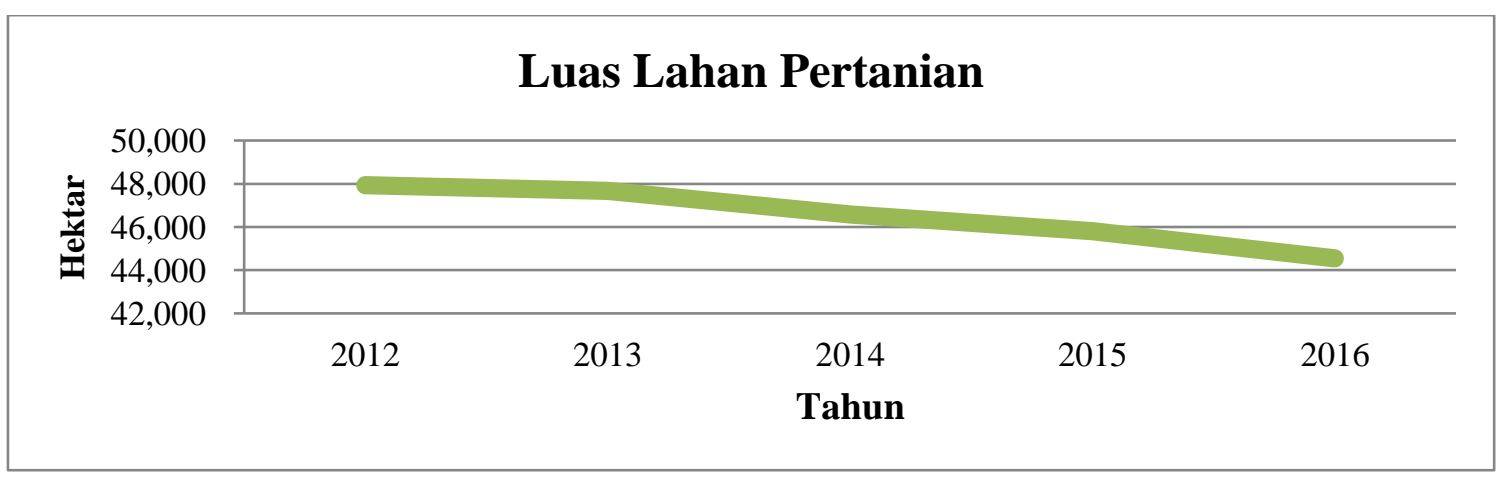

Sumber: Dinas Tanaman Pangan Hortikutura dan Perkebunan Kabupaten Bogor

Gambar 1. Luas lahan pertanian Tahun 2012 s/d 2016 di Kabupaten Bogor

Gambar diatas menunjukkan penurunan jumlah lahan sawah dlam kurun waktu 5 tahun terkahir dimulai dari Tahun 2012 s/d 2013 sebanyak 269 ha,
Tahun 2013 s/d 2014 sebanyak 1080 ha. Tahun 2014 s/d 2015 sebanyak 785 ha dan tahun 2015 s/d 2016 sebanyak 1251 ha dengan jumlah total 3385 ha dalam kurun 
waktu 5 tahun

Dalam

rangka mewujudkan

pemenuhan kebutuhan pangan

masyarakat, pemerintah Kabupaten

Bogor sedang mengupayakan perlindungan lahan pertanian pangan berkelanjutan sebagai salah satu bentuk perlindungan dan jaminan terhadap ketersediaan lahan secara berkelanjutan sebagai sumber pekerjaan dan penghidupan yang layak bagi petani. Berdasarkan hal tersebut, perlu dilakukan suatu penelitian menyangkut bagaimana strategi pengendalian alihfungsi terhadap perlindungan lahan pertanian pangan berkelanjutan di

Kabupaten Bogor.

Penelitian ini bertujuan untuk merumuskan strategi Pemerintah Kabupaten Bogor melalui strategi pengendalian alihfungsi lahan pertanian pangan berkelanjutan guna memenuhi tingkat kecukupan pangan dan melindungi dari laju konversi lahan. Untuk mendukung tujuan utama tersebut, perlu ditetapkan tujuan spesifik, meliputi

1. Jumlah Peruntukan ruang yang dapat dimanfaatkan untuk pengembangan komoditi pertanian;

2. Merumuskan strategi dengan melibatkan pihak lain di luar Pemerintahan.

Hasil penelitian sebelumnya yang dilakukan oleh Nasution dan Winoto (1996) yang mengulas pengaruh kelembagaan dalam perubahan fungsi lahan, Harjono (2010) menunjukkan hasil kurangnya sanksi, komimen pemerintah dan perilaku masyarakat, Handari (2012) dan Rahmawan (2013) dengan hasil Implementasi kebijakan perlindungan lahan pertanian berkelanjutan tersebut baru sampai pada tahap identifikasi lokasi dan belum ada suatu peraturan daerah yang mengatur tentang hal tersebut.

\section{METODOLOGI}

Sasaran kajian ini adalah Strategi Pengendalian Alihfungsi Lahan Pertanian Pangan Berkelanjutan di Kabupaten Bogor, data sekunder yaitu berupa luas lahan sawah Kabupaten Bogor tahun 2012 sampai dengan tahun 2016 dan lokasi rencana penetapan PLP2B bersumber dari Dinas Tanaman Pangan Hortikultura dan Perkebunan, Kajian PSP3 Institut Pertanian Bogor, juga Peta dari Badan Informasi Geospasial. Metode analisis yang digunakan:

1. Analisis deskripsi untuk menggambarkan alihfungsi lahan di Kabupaten Bogor.

2. Analisis Analytical Hierarchy Process (AHP)

Pengkajian AHP dimulai dengan menata elemen suatu persoalan dalam bentuk hierarki, kemudiaan dilanjutkan dengan membuat pemandingan berpasang antar elemen dan suatu tingkat sesuai dengan yang diperlukan oleh kriteriakriteria yang berada setingkat lebih tinggi. Berbagai pembandingan ini menghasilkan prioritas dan akhirnya, melalui sintesis, menghasilkan prioritas menyeluruh. Metode ini dikembangkan oleh Thomas L. Saaty pada tahun 1970-an, yang menggunakan persepsi manusia yang dianggap pakar atau ahli sebagai input utamanya.

Perumusan strategi perlindungan lahan pertanian pangan berkelanjutan di Kabupaten Bogor menggunakan metode Analytical Hierarchy Process (AHP) melalui wawancara terhadap pejabat dari unsur Dinas Tanaman Pangan Hortikultura dan Pekebunan dalam hal ini pengembil kebijakan yaitu Kepala dinas yang menjadi responden, unsur Swasta merupakan pimpinan perusahaan / direktur yang berusaha di bidang pertanian, unsurAkademisi yang diwakili oleh Kepala Pusat Studi di sebuah universitas serta unsur LSM yang fokus di bidang pertanian. 
Kriteria pakar atau ahli yang digunakan dalam analisis AHP ini lebih mengacu pada orang yang mengerti benar permasalahan yang diajukan, merasakan akibat suatu masalah atau memiliki kepentingan terhadap masalah tersebut (Falatehan, 2016).

Fokus

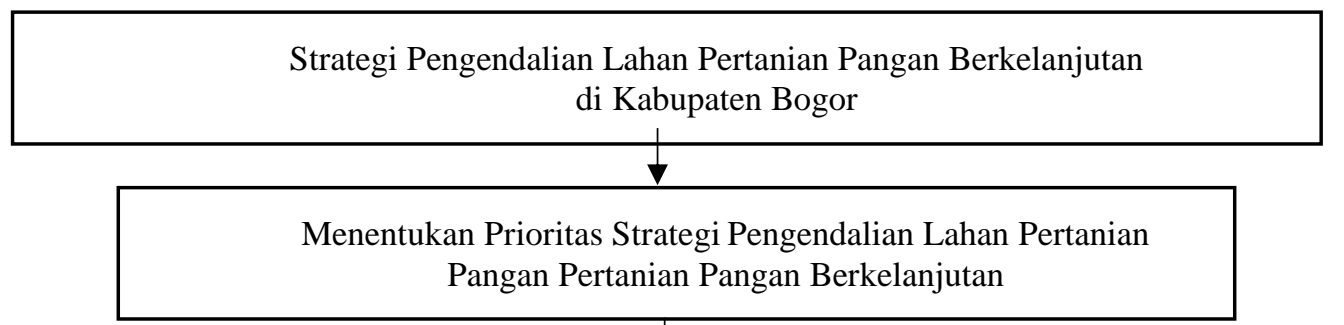

Tujuan

Faktor

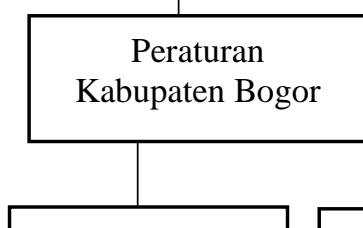

Stakeholde

ro

Kab. Bogor

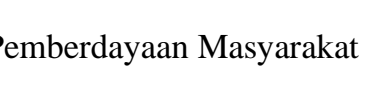

Penelitian menyeluruh LP2B

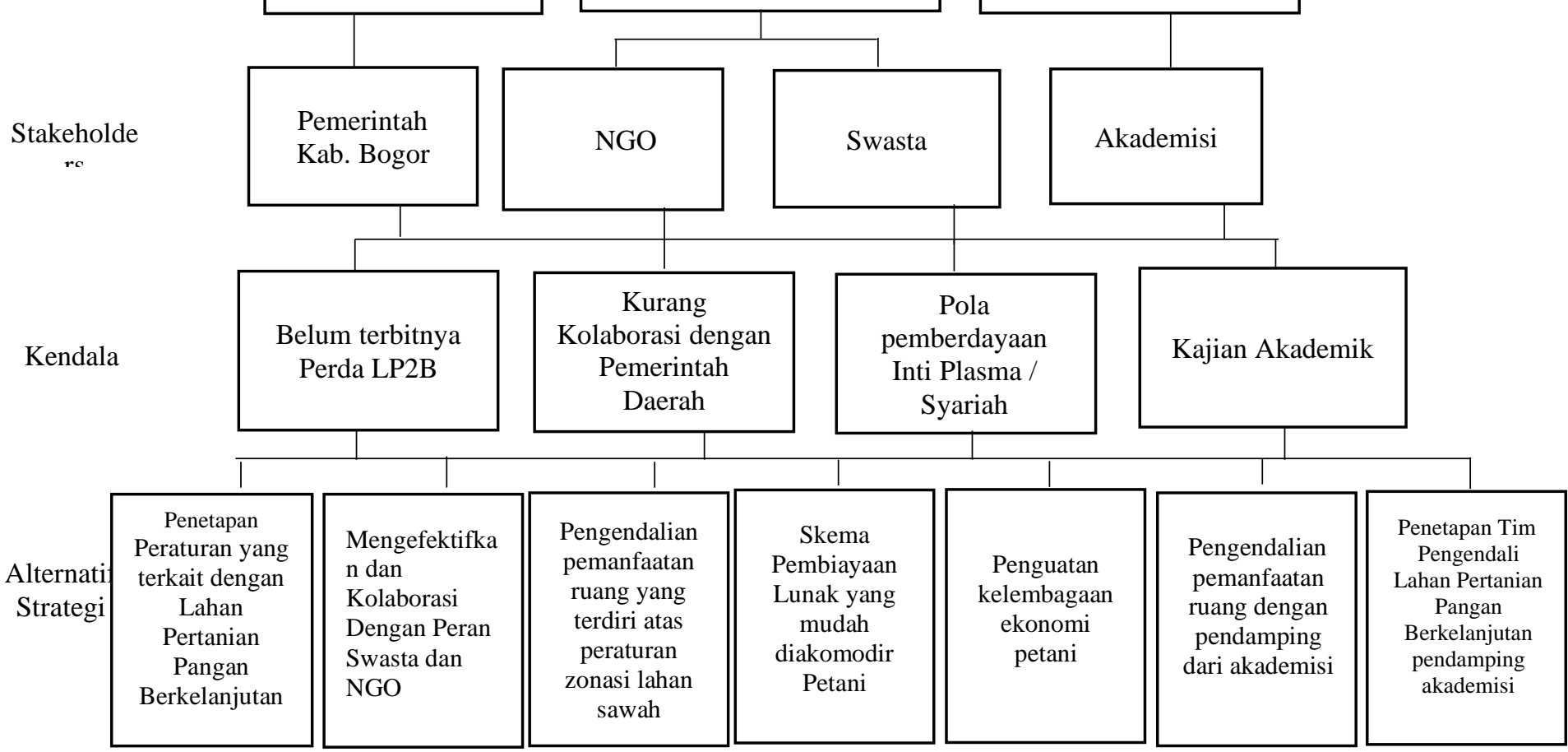

Gambar 2 Struktur hirarki AHP strategi Perlindungan Lahan Pertanian Pangan Berkelanjutan di Kabupaten Bogor

Struktur AHP (Gambar 2) yang digunakan terdiri dari enam hirarki (level). Hirarki pertama adalah goal atau tujuan utama sebagai fokus strategi. Hirarki kedua adalah tujuan perlindungan lahan pertanian pangan berkelanjutan. Hierarki ketiga adalah faktor yang menjadi perlindungan lahan pertanian, hirarki keempat adalah aktor yang memiliki peran utama di dalam upaya perlindungan lahan pertanian pangan berkelanjutan, yaitu Pemerintah daerah, swasta, NGO dan Akademisi. Hirarki kelima adalah kendala implementasi Lahan Pertanian Panagn Berkelanjutan, dan Herarki Keenam merupakan alternatif strategi yang direkomendasikan. 


\section{HASIL DAN PEMBAHASAN}

\section{Rencana Tata Ruang Rencana Wilayah (RTRW) mengakomodir Lahan Pertanian Pangan Berkelanjutan (LP2B) di Kabupaten Bogor}

Tersedianya peruntukan ruang untuk lahan pertanian seluas 58.044,93 atau sebesar $19,44 \%$ dari total luas wilayah Kabupaten Bogor sedangkan lahan sawah pada tahun 2016 ada berada pada angka $44.658 \mathrm{Ha}$, artinya perluasan lahan pertanian relatif dibatasi sedangkan perencanaan kawasan permukiman di Kabupaten Bogor seluas 104.494,40 Ha atau sekitar 34,88 \% total luas Kabupaten Bogor, dilihat pada tabel 2.

Tabel 2. Luasan Kawasan Budidaya Kabupaten Bogor (diolah)

\begin{tabular}{|c|c|c|c|}
\hline No & Kawasan Budidaya & Luas (Ha) & \% terhadap Luas Kabupaten \\
\hline 1 & $\overline{\text { Kawasan Peruntukkan Pertanian }}$ & $58.044,93$ & $\overline{19,44 \%}$ \\
\hline 2 & Lahan Basah & 38.016 .52 & $12,73 \%$ \\
\hline & TOTAL LAHAN & & $251.576,46$ \\
\hline
\end{tabular}

Luas lahan terbangun secara dominan terlihat berkembang dengan pesat di wilayah tengah dengan laju konversi lahan mencapai $1.288 \mathrm{Ha}$ per tahun. Periode tahun 2005-2010 merupakan periode puncak perkembangan alih fungsi lahan yang mencapai lebih dari 4.000 ha per tahun.
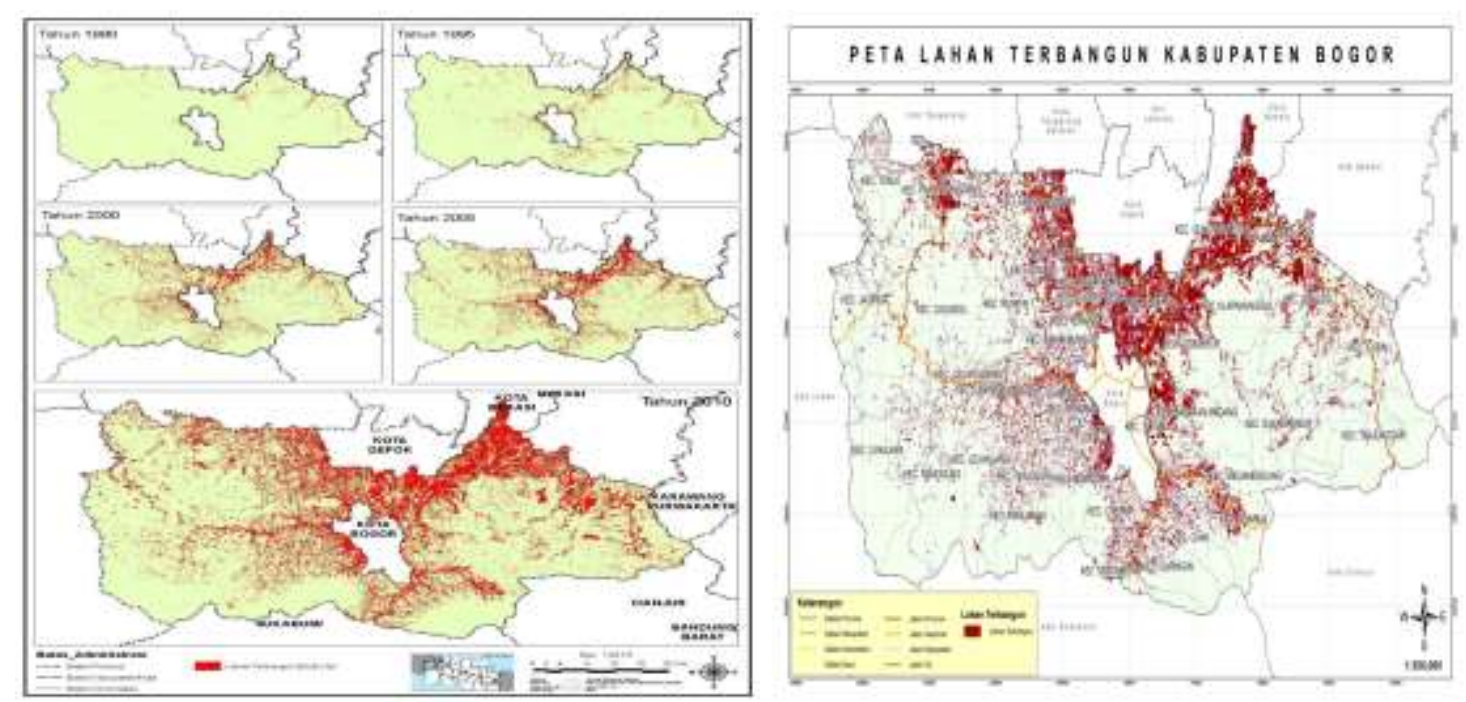

Sebelumnya pada periode tahun 19952000 juga terjadi konversi lahan yang cukup tinggi sebesar lebih dari 3.500 ha/tahun. Itu menandakan perlu langkah penguatan di wilayah lahan-lahan pertanian untuk penguatan pengembangan kawasan pertanian sebeluam dialihfungsi dan berubah penggunaan.

Gambar 3. Lahan Terbangun Wilayah Kabupaten Bogor Tahun 1990, 1995, 2000, 2005 2010, dan 2015

Pembahasan tentang Rencana Tata Ruang Rencana Wilayah (RTRW) mengakomodir pengembangan komoditi pertanian khususnya Lahan Pertanian Bogor adalah tesedianya peruntukan

ruang untuk lahan pertanian seluas $58.044,93$ atau sebesar $19,44 \%$ dari total luas wilayah Kabupaten Bogor sedangkan lahan sawah pada tahun 2016 ada berada pada angka $44.658 \mathrm{Ha}$, artinya perluasan lahan pertanian relatif dibatasi sedangkan 
perencanaan kawasan permukiman di Kabupaten Bogor seluas 104.494,40 Ha atau sekitar 34,88 \% total luas Kabupaten Bogor, luas lahan terbangun secara dominan terlihat berkembang dengan pesat di wilayah tengah dengan laju konversi lahan mencapai 1.288 Ha per tahun. Periode tahun 2005-2010 merupakan periode puncak perkembangan alih fungsi lahan yang mencapai lebih dari 4.000 ha per tahun. Sebelumnya pada periode tahun 19952000 juga terjadi konversi lahan yang cukup tinggi sebesar lebih dari 3.500 ha/tahun. Itu menandakan perlu langkah penguatan di wilayah lahan-lahan pertanian untuk penguatan pengembangan kawasan pertanian sebeluam dialihfungsi dan berubah penggunaan. Strategi pengembangan komoditi pertanian lingkup Lahan pertanian pangan berkelanjutan yang disebut kawasan budidaya dilakukan melalui (a) strategi untuk perwujudan dan peningkatan keterpaduan dan keterkaitan antar kegiatan budi daya, meliputi penetapan kawasan budidaya yang memiliki nilai strategis nasional untuk pemanfaatan sumber daya alam di ruang darat, ruang udara, dan termasuk ruang di dalam bumi secara sinergis untuk mewujudkan keseimbangan pemanfaatan ruang wilayah; pengembangan kegiatan budi daya unggulan di dalam kawasan beserta prasarana secara sinergis dan berkelanjutan untuk mendorong pengembangan perekonomian kawasan dan wilayah sekitarnya; pengembangan kegiatan budidaya untuk menunjang aspek politik, pertahanan dan keamanan, sosial budaya, serta ilmu pengetahuan dan teknologi; dan pengembangan dan pelestarian kawasan budidaya pertanian pangan untuk mewujudkan ketahanan pangan nasional; (b) strategi untuk pengendalian perkembangan kegiatan budi daya agar tidak melampaui daya dukung dan daya tampung lingkungan, meliputi pembatasan perkembangan kegiatan budi daya terbangun di kawasan rawan bencana. Pengembangan kawasan perkotaan dengan mengoptimalkan pemanfaaatan ruang secara vertikal; pengembangan ruang terbuka hijau dengan luas paling sedikit 30\% (tiga puluh persen) dari luas kawasan perkotaan; dan (c) strategi untuk pengembangan fasilitas perkotaan yang dapat mendukung kegiatan pedesaan sebagai basis perekonomian daerah dan dalam rangka menekan migrasi penduduk dari desa ke kota.

\section{Pentingnya Peraturan Desa tentang Tata Ruang}

Penataan ruang kawasan perdesaan dalam 1 (satu) wilayah kabupaten dapat dilakukan pada tingkat wilayah kecamatan atau beberapa wilayah desa atau nama lain yang disamakan dengan desa yang merupakan bentuk detail dari penataan ruang wilayah Kabupaten. Rencana tata ruang kawasan perdesaan yang mencakup 2 (dua) atau lebih wilayah kabupaten merupakan alat koordinasi dalam pelaksanaan pembangunan yang bersifat lintas wilayah. Rencana tata ruang sebagaimana dimaksud di atas berisi struktur ruang dan pola ruang yang bersifat lintas wilayah administratif. didasarkan pada UU Nomor 6 Tentang Desa. Desa memiliki kewenangan untuk mengatur tata ruang desa, dengan syarat tidak bertentangan dengan Peraturan Daerah dan peraturan yang lain di atasnya. Kabupaten Bogor telah memiliki Perda Nomor 11 Tahun 2016 tentang Rencana Tata Ruang Wilayah (RTRW) Kabupaten Bogor 2016-2036 Pemerintah desa bisa menerjemahkan Perda itu pada lingkup lokal skala desa dengan dibuatkan Peraturan Desa. Peraturan Desa akan menjaga lahan pertanian agar tidak beralih fungsi. Dalam peraturan desa tersebut, pemerintah desa dan BPD bisa mengatur, wilayah mana saja yang akan menjadi lahan pertanian, pariwisata, perumahan dan atau komoditas apa yang bisa diunggulkan di desa tersebut. Dengan demikian, alih fungsi lahan pertanian di desa bisa diminimalisir 
Tabel 3. Pola, Strategi, dan Arah Pemanfaatan Lahan Pertanian Pangan di Kabupaten Bogor

\begin{tabular}{|c|c|c|}
\hline Pola Pemanfaatan & Strategi Pemanfaatan & Arah Pemanfaatan \\
\hline $\begin{array}{l}\text { Kawasan yang secara teknis } \\
\text { dapat digunakan untuk } \\
\text { pertanian sawah } \\
\text { Kawasan yang apabila } \\
\text { digunakan untuk kegiatan } \\
\text { pertanian sawah secara } \\
\text { ruang dapat memberikan } \\
\text { manfaat : (a) peningkatan } \\
\text { produksi pangan dan } \\
\text { mendayagunakan investasi } \\
\text { yang telah ada; } \\
\text { b) meningkatkan } \\
\text { perkembangan sektor dan } \\
\text { kegiatan ekonomi } \\
\text { sekitarnya; dan (c) upaya } \\
\text { pelestarian sumberdaya } \\
\text { alam untuk sawah. } \\
\text { Memiliki kemampuan } \\
\text { swasembada pangan } \\
\text { berkelanjutan } \\
\text { Memiliki kemampuan } \\
\text { mendayagunakan investasi } \\
\text { yang telah ditanam miliki } \\
\text { kemampuan meningkatkan } \\
\text { pendapatan petani dan } \\
\text { daerah } \\
\text { Mempunyai peluang } \\
\text { sebagai sektor strategis di } \\
\text { daerah bersangkutan }\end{array}$ & $\begin{array}{l}\text { Melakukan intensifikasi untuk lahan } \\
\text { pertanian beririgasi teknis yang } \\
\text { berada dalam wilayah perkotaan } \\
\text { Melakukan ekstensifikasi pada } \\
\text { lahan pertanian di luar wilayah } \\
\text { perkotaan atau pinggiran/pheri- } \\
\text { pheri dalam. } \\
\text { Meminimalisasi alih } \\
\text { fungsi/konversi lahan pertanian } \\
\text { menjadi lahan pemukiman dan } \\
\text { perkotaan, khususnya lahan yang } \\
\text { beririgasi teknis } \\
\text { Jika terpaksa konversi lahan } \\
\text { pertanian menjadi kawasan } \\
\text { pemukiman dan aktivitas budidaya } \\
\text { non- pertanian dilakukan, maka } \\
\text { harus dalam batasan sebagai } \\
\text { berikut : } \\
\text { Lahan pertanian/sawah dua kali } \\
\text { panen setahun, sawah satu kali } \\
\text { panen padi dan dua kali panen } \\
\text { palawija, sawah tidak ditanami padi } \\
\text { tapi palawija dua kali panen, dan } \\
\text { perkebunan. } \\
\text { Lahan non-produktif (memiliki } \\
\text { keterbatasan fisik alamiah), misal } \\
\text { sawah tadah hujan dengan } \\
\text { kelerengan lebih kurang } 15 \% \\
\text { Menyelesaikan persoalantumpang } \\
\text { tindih dengan kegiatan potensial } \\
\text { lainnya } \\
\text { Pengembangan prasarana irigasi } \\
\text { pertanian } \\
\text { Pengembangan produk pertanian } \\
\text { unggulan yang berorientasi industri }\end{array}$ & $\begin{array}{l}\text { Memperluas lahan } \\
\text { sawah beririgasi teknis } \\
\text { pada sawah yang dapat } \\
\text { dipanen dua sampai tiga } \\
\text { kali setahun } \\
\text { Menghindari konversi } \\
\text { lahan pertanian } \\
\text { beririgasi teknis untuk } \\
\text { kegiatan lain } \\
\text { Memelihara dan } \\
\text { meningkatkan kualitas } \\
\text { prasarana pengairan } \\
\text { Konversi lahan } \\
\text { pertanian diijinkan } \\
\text { dengan catatan nilai } \\
\text { ekonomi yang ada lebih } \\
\text { tinggi atau untuk } \\
\text { kebutuhan mendesak } \\
\text { pada lahan sawah tadah } \\
\text { hujan } \\
\text { Jika kebutuhan } \\
\text { mendesak, perlu } \\
\text { perluasan areal sawah } \\
\text { baru. }\end{array}$ \\
\hline
\end{tabular}

Sumber : Hasil penelitian

\section{Strategi Perlindungan Lahan}

Pertanian Pangan Berkelanjutan di

Kabupaten Bogor menggunakan Analisis AHP

Berdasarkan hasil analisis AHP dengan fokus strategi pengendalian lahan pertanian pangan berkelanjutan di

Kabupaten Bogor bertujuan menentukan prioritas Strategi Pengendalian Lahan Pertanian Pangan Pertanian Pangan Berkelanjutan fokus pada level faktor yang menjadi prioritas adalah pemberdayaan masyarakat, hal tersebut adalah upaya untuk memberikan daya (empowerment) atau penguatan (strengthening) kepada masyarakat. Pada 
Level stakeholders untuk Faktor pemberdayaan masyarakat lebih prioritas pada swasta. Pada Level kendala memiliki prioritas yaitu kurang kolaborasi dengan pemerintah daerah. Pada level ini perlu dilakukan penyamaan persepsi dan kerja bersama antara Pemerintah, swasta dan NGO, pada level alternatif strategi memiliki prioritas pada penetapan tim pengendali lahan pertanian pangan berkelanjutan pendamping akademisi. Konsep pemberdayaan masyarakat secara mendasar berarti menempatkan masyarakat beserta institusi-institusinya sebagai kekuatan dasar bagi pengembangan ekonomi, politik, sosial, dan budaya menghidupkan kembali berbagai pranata ekonomi masyarakat untuk dihimpun dan diperkuat sehingga dapat berperan sebagai lokomotif bagi kemajuan ekonomi merupakan keharusan untuk dilakukan ekonomi rakyat akan terbangun bila hubungan sinergis dari berbagai pranata sosial dan ekonomi yang ada didalam masyarakat dikembangkan kearah terbentuknya jaringan ekonomi rakyat.

\section{Analisis Vertikal}

Fokus

Tujuan

Faktor

\section{Stakeholders}

Kendala

Alternatif Strategi

Strategi Pengendalian Lahan Pertanian Pangan Berkelanjutan di Kabupaten Bogor

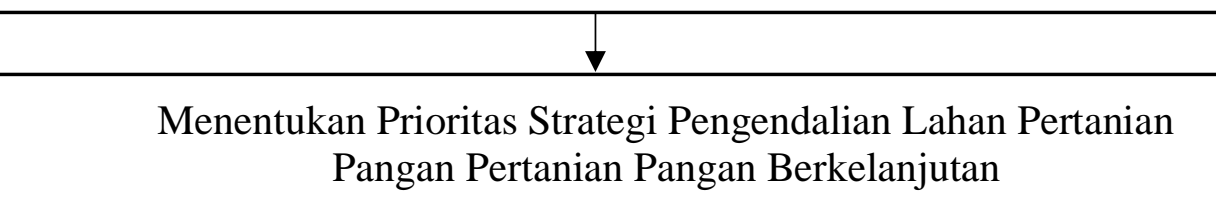

Pangan Pertanian Pangan Berkelanjutan

Peraturan

Kabupaten Bogor (0.171)

Pemberdayaan

Masyarakat (0.559)

Penelitian

menyeluruh LP2B (0.270)

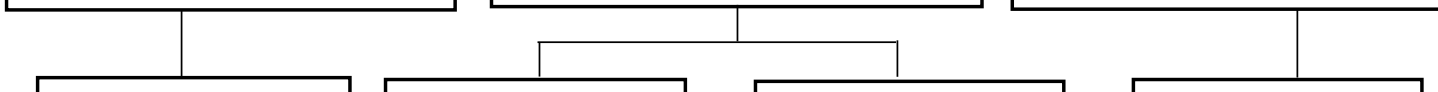

Pemerintah

Kabupaten

NGO

(0.285)

Swasta

(0.715)

(1)

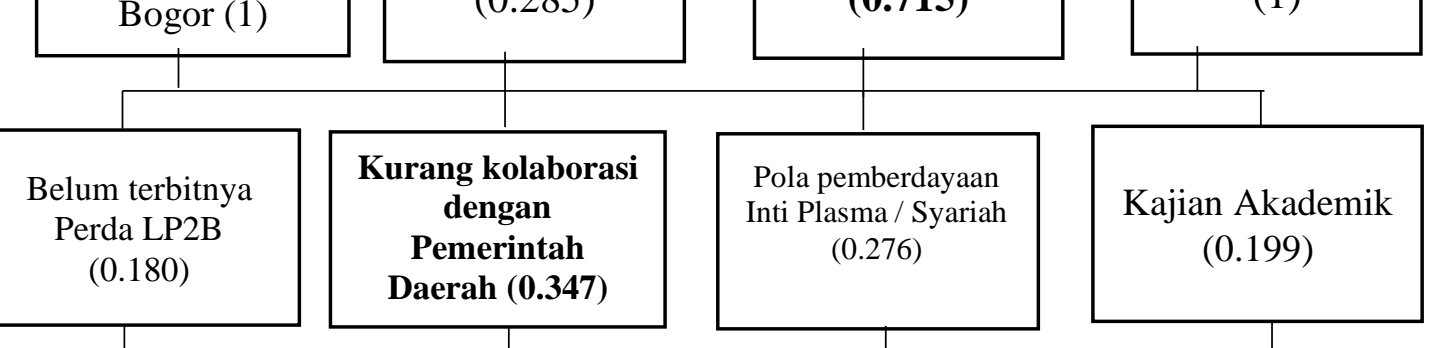

Penetapan

Peraturan yang

terkait dengan

Lahan

Pertanian

Pangan

Berkelanjutan

(0.115)
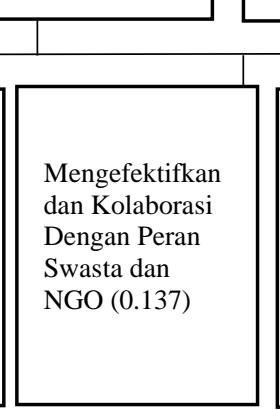

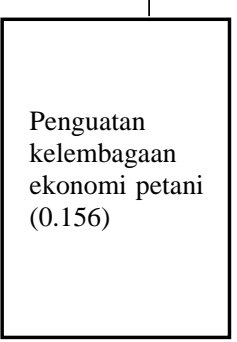

\begin{tabular}{|c|c|}
\hline $\begin{array}{c}\text { Pengendalian } \\
\text { pemanfaatan } \\
\text { ruang dengan } \\
\text { pendamping } \\
\text { dari } \\
\text { akademisi } \\
(0.103)\end{array}$ & $\begin{array}{l}\text { Penetapan Tim } \\
\text { Pengendali } \\
\text { Lahan Pertanian } \\
\text { Pangan } \\
\text { Berkelanjutan } \\
\text { pendamping } \\
\text { akademisi }(0.215)\end{array}$ \\
\hline
\end{tabular}

Gambar 4. Struktur dan nilai bobot hirarki strategi perlindungan lahan pertanian pangan berkelanjutan di Kabupaten Bogor

Berdasarkan hasil analisis vertikal, pada level faktor yang menjadi prioritas adalah pemberdayaan masyarakat. Konsep pemberdayaan masyarakat secara 
mendasar berarti menempatkan masyarakat beserta institusi-institusinya sebagai kekuatan dasar bagi pengembangan ekonomi, politik, sosial, dan budaya menghidupkan kembali berbagai pranata ekonomi masyarakat untuk dihimpun dan diperkuat sehingga dapat berperan sebagai lokomotif bagi kemajuan ekonomi merupakan keharusan untuk dilakukan ekonomi rakyat akan terbangun bila hubungan sinergis dari berbagai pranata sosial dan ekonomi yang ada didalam masyarakat dikembangkan kearah terbentuknya jaringan ekonomi rakyat.

Konsep pemberdayaan masyarakat secara mendasar berarti menempatkan masyarakat beserta institusi-institusinya sebagai kekuatan dasar bagi pengembangan ekonomi, politik, sosial, dan budaya menghidupkan kembali berbagai pranata ekonomi masyarakat untuk dihimpun dan diperkuat sehingga dapat berperan sebagai lokomotif bagi kemajuan ekonomi merupakan keharusan untuk dilakukan ekonomi rakyat akan terbangun bila hubungan sinergis dari berbagai pranata sosial dan ekonomi yang ada didalam masyarakat dikembangkan kearah terbentuknya jaringan ekonomi rakyat.

Pada Level stakeholders untuk Faktor pemberdayaan masyarakat lebih prioritas pada Swasta. Pada Level kendala memiliki prioritas yaitu Kurang Kolaborasi dengan Pemerintah Daerah. Karena itulah perlu dibangun seinergitas pelaku usaha, Pemerintah dengan NGO dalam hal ini lembaga wakaf untuk terus melindungi serta membangun usaha produktif kegiatan pertanian, pada level alternatif strategi memiliki prioritas pada Penetapan Tim Pengendali Lahan Pertanian Pangan Berkelanjutan pendamping akademisi. Oleh karena itu menjadi keniscayaan bahwa Pemerintah Daerah bersama para akademisi mencanangkan program berkelanjutan dengan tujuan penetapan tim pengendali Lahan Pertanian Pangan Berkelanjutan.

\section{Analisis Horizontal}

Tabel 4. Bobot setiap Kendala terhadap Stakeholders

\begin{tabular}{lrrrr}
\hline \multirow{2}{*}{ Kendala } & \multicolumn{4}{c}{ Stakeholders } \\
\cline { 2 - 5 } & Pemerintah Kab. Bogor & NGO & Swasta & Akademisi \\
\hline Belum terbitnya Perda LP2B & 0.135 & 0.144 & 0.194 & 0.380 \\
Kurang Kolaborasi dengan Pemerintah Daerah & $\mathbf{0 . 3 6 7}$ & $\mathbf{0 . 3 0 8}$ & $\mathbf{0 . 3 6 2}$ & 0.180 \\
Pola Pemberdayaan Inti Plasma/syariah & 0.286 & 0.282 & 0.273 & 0.118 \\
Kajian Akademik & 0.211 & 0.266 & 0.172 & $\mathbf{0 . 3 2 3}$ \\
\hline Consistency ratio & 0.03 & 0.00 & 0.03 & 0.02 \\
\hline
\end{tabular}

Berdasarkan hasil diperoleh Consistency Ratio $(C R)<0.10$ artinya jawaban pakar telah konsisten. Stakeholders Pemerintah Kab. Bogor, NGO dan Swasta lebih memprioritaskan kendala Kurang Kolaborasi dengan Pemerintah Daerah, sedangkan stakeholders akademisi lebih memprioritaskan kendala pada kajian akademik dengan bobot sebesar 0.323.
Daerah LP2B memilih prioritas strategi pada Mengefektifkan dan Kolaborasi Dengan Peran Swasta dan NGO. kendala Kurang Kolaborasi dengan Pemerintah Daerah memilih prioritas strategi pada Penetapan Tim Pengendali Lahan Pertanian Pangan Berkelanjutan pendamping akademisi. kendala Pola Pemberdayaan Inti Plasma/syariah memilih prioritas strategi pada Skema Pembiayaan Lunak yang mudah diakomodir Petani dengan bobot sebesar 
0.204. kendala Kajian Akademik memilih prioritas strategi pada Pengendalian pemanfaatan ruang yang terdiri atas peraturan zonasi lahan sawah dengan bobot sebesar 0.273

Tabel 5. Bobot setiap Alternative Strategi terhadap Kendala

\begin{tabular}{ccccc}
\hline & $\begin{array}{c}\text { Belum } \\
\text { terbitnya } \\
\text { Perda LP2B }\end{array}$ & $\begin{array}{c}\text { Kurang Kolaborasi } \\
\text { dengan Pemerintah } \\
\text { Daerah }\end{array}$ & $\begin{array}{c}\text { Pola } \\
\text { Pemberdayaan } \\
\text { Inti } \\
\text { Plasma/syariah }\end{array}$ & $\begin{array}{c}\text { Kajian } \\
\text { Akade } \\
\text { mik }\end{array}$ \\
\hline $\begin{array}{c}\text { Penetapan Peraturan yang terkait } \\
\text { dengan Lahan Pertanian Pangan } \\
\text { Berkelanjutan }\end{array}$ & 0.137 & 0.061 & 0.147 & 0.099 \\
\hline $\begin{array}{c}\text { Mengefektifkan dan Kolaborasi } \\
\text { Dengan Peran Swasta dan NGO }\end{array}$ & $\mathbf{0 . 2 0 4}$ & 0.137 & 0.136 & 0.054 \\
$\begin{array}{c}\text { Pengendalian pemanfaatan ruang } \\
\text { yang terdiri atas peraturan zonasi } \\
\text { lahan sawah }\end{array}$ & 0.077 & 0.057 & 0.073 & $\mathbf{0 . 2 7 3}$ \\
$\begin{array}{c}\text { Skema Pembiayaan Lunak yang } \\
\text { mudah diakomodir Petani }\end{array}$ & 0.185 & 0.139 & $\mathbf{0 . 2 0 4}$ & 0.084 \\
$\begin{array}{c}\text { Penguatan kelembagaan ekonomi } \\
\text { petani }\end{array}$ & 0.156 & 0.147 & 0.172 & 0.145 \\
$\begin{array}{c}\text { Pengendalian pemanfaatan ruang } \\
\text { dengan pendamping dari akademisi } \\
\text { Penetapan Tim Pengendali Lahan } \\
\text { Pertanian Pangan Berkelanjutan } \\
\text { pendamping akademisi }\end{array}$ & 0.056 & 0.105 & 0.151 & 0.095 \\
\hline Consistency ratio & 0.186 & $\mathbf{0 . 3 5 2}$ & 0.116 & 0.249 \\
\hline
\end{tabular}

\section{SIMPULAN DAN SARAN}

\section{Simpulan}

Berdasarkan hasil dan pembahasan yang telah diuraikan untuk menjawab permasalahan yang telah dirumuskan, maka dapat diambil kesimpulan sebagai berikut:

Hingga saat ini, Terlihat dari Pola Ruang yang ditetapkan Peruntukan Lahan Basah telah ditetapkan seluas 38.016,52 Ha perlu langkah penguatan di wilayah lahan-lahan pertanian untuk penguatan pengembangan kawasan pertanian sebelum dialihfungsi dan berubah penggunaan. Berdasarkan hasil analisis Analytical Hierarki Process (AHP) konsep QuadrupleHelix merupakan pilar utama yang berperan mendorong perlindungan lahan pertanian pangan berkelanjutan yang meliputi empat sektor yaitu pemerintah, swasta, akademisi dan LSM/yayasan, dengan kolaborasi dan saling melengkapi diharapkan harga komoditi pertanian semakin kompetitif, kepemilikan lahan pertanian terlindungi, regulasi berjalan dinamis serta inovasi akan diimplementasikan dengan baik untuk kedaulatan pangan.

\section{Saran}

Berdasarkan kesimpulan hasil penelitian dapat direkomendasikan beberapa usulan kebijakan adalah titik tumpu (entry point) strategi pengendalian adalah komitmen bersama terutama pimpinan daerah dalam menyikapi alihfungsi lahan pertanian pangan berkelanjutan serta menjalankan konsekuensi setelah terbitnya peraturan mengenai Perlindungan Lahan Pertanian Pangan Berkelanjutan, sasaran (goal) 
strategi pengendalian adalah terwujudnya pengendalian alih fungsi lahan pertanian yang selaras dan berkelanjutan baik dari peraturan peruntukan ruang maupun kebijakan yang menguntungkan para pelaku usaha pertanian yang dikhusukan kepada petani.

\section{DAFTAR PUSTAKA}

Abubakar M. 2009. Kemandirian Pangan: Cadangan Publik, Stabilisasi Harga Dan Diversifikasi. Jurnal Litbang Pusat Analisis Sosial Ekonomi dan Kebijakan Pertanian.7(2): 107-129

Adam L. 2012.Urgensi Pembentukan Bank Pertanian Indonesia.Jurnal Litbang Pertanian Pusat Analisis Sosial Ekonomi dan Kebijakan Pertanian. 10(2): 103-117

Ashari. 2009. Peran perbankan nasional dalam pembiayaan sektor pertanian di Indonesia. Forum Penelitian Agro Ekonomi 27(1):13-27.

Aliadi A. 2011. Pengembangan Kolaborasi Taman Nasional Gunung Ciremai: Kajian Melalui Riset Aksi[tesis]. Bogor (ID): Institut Pertanian Bogor.

[BAPPEDA]Badan Perencanaan Pembangunan Daerah Kabupaten Bogor \&[PSP3] Pusat Studi Pembangunan Pertanian dan Perdesaan-IPB. 2010.

Kaji Tindak Pengembangan Kelembagaan Sistem Pendanaan Dan Pemasaran Dalam Revitalisasi Pertanian Di Kabupaten Bogor. Bogor (ID): PSP3-IPB.

Barus, B., D.R. Panuju, L.S. Iman, B.H.Trisasongko , K. Gandasasmita, dan R. Kusumo. 2010. Pemetaan Potensi Konversi Lahan Sawah dalam Kaitan Lahan Pertanian Berkelanjutan dengan Analisis Spasial. Pusat Pengkajian
Direktorat Pemberdayaan Wakaf, 2008, Model Pengembangan Wakaf Produktif, Jakarta: Direktorat Pemberdayaan Wakaf.

Falatehan, A. Faroby. 2016. Analytical Hierarchy Process (AHP) Teknik Pengambilan Keputusan untuk Pembangunan Daerah. Yogyakarta : Indomedia Pustaka.

[FAO]Food and Agricultural Organization. 2008.Socio-Economic And Livelihood Analisys In Investment In Planning.

Ferroni, M. and P. Castle. 2011. Publicprivate partnerships and sustainable agricultural development. Sustainability 3:1064-1073; doi:10.3390/su3071064. Open Access Sustainability

ISSN 2071-1050.

http://www.mpdi.com/journal/sustaina bility. (13 Juli 2018).

Iqbal M, Sumaryanto. 2007. Strategi Pengendalian Alih Fungsi Lahan Pertanian Bertumpu Pada partisipasi masyarakat. Jurnal Litbang Pertanian Pusat Analisis Sosial Ekonomi dan Kebijakan Pertanian. 5(2): 167-182.

Kementerian Pertanian. 2012. Evaluasi Pelaksanaan Gerakan Peningkatan Produksi Pangan Berbasis Korporasi (GP3K). Jakarta: Biro Perencanaan, Kementerian Pertanian.

Kriteria Teknis Kawasan Peruntukan Pertanian. Jakarta (ID): Kementan

Mubarok, Jaih, 2008, Wakaf Produktif, Bandung: Simbiosa Rekatama Media.

Pemerintah Republik Indonesia. 2009. Undang-undang Nomor 41 Tahun 2009 tentang Perlindungan Lahan Pertanian Berkelanjutan. Jakarta (ID): Sekretariat Negara.

Presiden Republik Indonesia. 2007. Undang-undang Negara Republik Indonesia Nomer 26 tahun 2007 Tentang Penataan Ruang. 
Syauqi Beik, Irfan dan Winda Nur Apriani. 2013. Analisis Faktor faktor yang memengaruhi pembiayaan bank syariah untuk sektor pertanian. Jurnal Agro Ekonomi 31(1).

Tonny F. 2011. Bahan Kuliah KPM 53C: Pengembangan Masyarakat dan Kelembagaan Daerah Bagian $C$. Bogor (ID): Manajemen Pembangunan Daerah IPB. 